\title{
Microcornea associated with retinopathy of prematurity
}

\author{
S P KELLY AND A R FIELDER \\ From the Department of Ophthalmology, Leicester University Medical School
}

SUMMARY Eight children with retinopathy of prematurity (ROP) in whom the corneal diameters were abnormally small in one or both eyes are reported. The mechanisms for microcornea in ROP are discussed. The differential diagnosis of microphthalmos is briefly considered.

Anterior segment abnormalities are known to occur in association with retinopathy of prematurity (ROP). Recently attention has been directed mainly to anomalies of corneal curvature, and Hittner and coworkers $^{1}$ reported abnormally steep keratometry readings associated with shallowing of the anterior chamber. Microphthalmos was reported in the early ROP literature, ${ }^{2-5}$ later confirmed by ocular ultrasonography, ${ }^{67}$ and was considered an accompaniment of advanced cicatricial disease. Since then this aspect of ROP has received little attention.

We present here the cases of eight infants with ROP who also had reduced corneal diameters. In seven of the eight serial measurements were obtained over a minimum period of 15 months. We will discuss this association, consider the possible mechanisms involved in its production, and indicate that in contrast to earlier studies microcornea is not necessarily a sign of advanced cicatricial ROP.

\section{Patients and methods}

Eight infants with ROP and reduced corneal diameters have been studied. With the exception of infant 2 all were first examined as part of a routine screening for ROP in one of five neonatal units in Derby, Nottingham, and Leicester. All examinations were performed by ARF using indirect ophthalmoscopy and scleral indentation. Observation for ROP began in the third week of life and continued weekly, clinical condition permitting, until the infant's discharge from hospital and thereafter as needed. Acute ROP was graded according to the new International Classification $^{8}$ and the cicatricial changes according to Reese et al. ${ }^{9}$ Infants who received cryoretinal

Correspondence to A R Fielder, FRCS, Department of Ophthalmology, Clinical Sciences Building, Leicester Royal Infirmary, PO Box 65, Leicester LE2 7LX. treatment for acute ROP were excluded from this study. Measurements of horizontal corneal diameter were made with a hand held calliper and rule when infants were on the neonatal unit, or with a ruler after this time. Ocular ultrasound was not performed.

\section{Results}

Eight infants, four of each sex, are presented. Gestational ages ranged from between 25.0 and 31.0 weeks and birth weights from 780 to $1360 \mathrm{~g}$. The major systemic problems encountered in the neonatal period are shown in Table 1. All had stormy neonatal periods and all received supplemental oxygen.

The ocular details are listed in Table 2. They

Table 1 Details of patients

\begin{tabular}{|c|c|c|c|}
\hline Case & Sex & $\begin{array}{l}\text { Birth weight }(g) / \\
\text { gestation (weeks) }\end{array}$ & Neonatal problems \\
\hline 1 & $\mathbf{F}$ & $860 \mathrm{~g} / 27 \cdot 0$ & $\begin{array}{l}\text { RDS, PDA, hypothermia } \\
\text { anaemia }\end{array}$ \\
\hline 2 & $\mathbf{F}$ & $1120 \mathrm{~g} / 28 \cdot 0$ & RDS, anaemia \\
\hline 3 & $\mathbf{M}$ & $1340 \mathrm{~g} / 29 \cdot 0$ & $\begin{array}{l}\text { RDS, PDA, pneumothorax, } \\
\text { IVH }\end{array}$ \\
\hline 4 & $\mathbf{M}$ & $1360 \mathrm{~g} / 29 \cdot 0$ & $\begin{array}{l}\text { RDS, IVH, pul. haem., ex. } \\
\text { transf. }\end{array}$ \\
\hline 5 & $\mathbf{F}$ & $980 \mathrm{~g} / 28 \cdot 0$ & $\begin{array}{l}\text { RDS, PDA, pneumothorax, } \\
\text { pneumonia, anaemia, CCF }\end{array}$ \\
\hline 6 & $\mathbf{M}$ & $1300 \mathrm{~g} / 31 \cdot 0$ & $\begin{array}{l}\text { RDS, PDA, pneumothorax, } \\
\text { IVH, DIC, septicaemia }\end{array}$ \\
\hline 7 & $\mathbf{M}$ & $780 \mathrm{~g} / 25 \cdot 0$ & $\begin{array}{l}\text { RDS, PDA, pneumonia IVH, } \\
\text { septicaemia, anaemia }\end{array}$ \\
\hline 8 & $\mathbf{F}$ & $780 \mathrm{~g} / 25 \cdot 0$ & $\begin{array}{l}\text { RDS, PDA, pneumothorax } \\
\text { pneumonia }\end{array}$ \\
\hline
\end{tabular}

RDS $=$ Respiratory distress syndrome. PDA $=$ Patent ductus arteriosus. IVH=Intraventricular haemorrhage. DIC $=$

Disseminated intravascular coagilopathy. Ex. Transf. $=$ Exchange transfusion. Pul. haem=Pulmonary haemorrhage.

Cases 7 and 8 are twins. 
Table 2 Ocular details

\begin{tabular}{|c|c|c|c|c|c|c|c|c|}
\hline \multirow[t]{2}{*}{ Case } & \multicolumn{2}{|c|}{ Acute $R O P$} & \multicolumn{2}{|c|}{$\begin{array}{l}\text { Cicatricial } \\
\text { ROP }\end{array}$} & \multicolumn{2}{|c|}{$\begin{array}{l}\text { Refractive } \\
\text { Error }\end{array}$} & \multicolumn{2}{|c|}{$\begin{array}{l}\text { Corneal } \\
\text { diameter } \\
(\mathrm{mm})\end{array}$} \\
\hline & $R$ & $L$ & $R$ & $L$ & $R$ & $L$ & $R$ & $L$ \\
\hline $\begin{array}{l}1 \\
2\end{array}$ & $\begin{array}{l}\text { III+ } \\
\text { Not e }\end{array}$ & $\begin{array}{l}\text { III+ } \\
\text { xamined }\end{array}$ & $\begin{array}{l}\text { V } \\
\text { III }\end{array}$ & $\begin{array}{l}\text { I } \\
\text { IV }\end{array}$ & $\begin{array}{l}\text { NA } \\
\frac{-0.5}{-1.0} \\
\text { at } 90\end{array}$ & $\begin{array}{l}-13 \cdot 5 \\
\text { NA }\end{array}$ & $\begin{array}{r}9 \cdot 5 \\
11.0\end{array}$ & $\begin{array}{r}11 \cdot 0 \\
9.5\end{array}$ \\
\hline 3 & III + & IV & I & IV & $\begin{array}{l}\frac{-11 \cdot 0}{-2 \cdot 0} \\
\text { at } 100\end{array}$ & $+2 \cdot 0 \mathrm{DS}$ & $S 11 \cdot 0$ & $9 \cdot 5$ \\
\hline 4 & IV & IV & V & V & NA & NA & $10 \cdot 0$ & $10 \cdot 0$ \\
\hline 5 & III & II & I & 0 & $\begin{array}{l}\frac{-12.0}{-1.0} \\
\text { at } 180\end{array}$ & Plano & $10 \cdot 0$ & $11 \cdot 0$ \\
\hline 6 & III+ & III+ & III & II & Plano & $\begin{array}{l}\frac{-7 \cdot 0}{-1 \cdot 50} \\
\text { at } 180\end{array}$ & $10 \cdot 0$ & $11 \cdot 0$ \\
\hline $\begin{array}{l}7 \\
8\end{array}$ & $\begin{array}{l}\text { III+ } \\
\text { III+ }\end{array}$ & $\begin{array}{l}\text { III+ } \\
\text { III+ }\end{array}$ & $\begin{array}{l}\text { III } \\
\text { I }\end{array}$ & $\begin{array}{l}\text { I } \\
\text { I }\end{array}$ & $\begin{array}{l}-5 \cdot 0 \\
-7 \cdot 0\end{array}$ & $\begin{array}{l}-6 \cdot 0 \\
-9 \cdot 0\end{array}$ & $\begin{array}{l}10 \cdot 0 \\
10 \cdot 5\end{array}$ & $\begin{array}{l}10 \cdot 0 \\
11.0\end{array}$ \\
\hline
\end{tabular}

NA= Retinoscopy impossible owing to retrolental opacity. Values for refractive errors and corneal diameters are from the most recent follow-up.

include the maximum grades of acute and cicatricial ROP reached, the refractive status, and the horizontal corneal diameters at the most recent outpatient visit.

Measurements of corneal diameter began at 36 weeks postmenstrual age (cases 7 and 8), and corrected ages of 1 month (case 3), 2 months (cases 1 and 4 ), and $31 / 2$ months (case 6 ). For infants 2 and 5 measurements were not made until ages $2 \frac{1}{2}$ and $3 \frac{1}{2}$ years respectively. Except for case 2 all infants had serial assessments over a minimum period of 15 months, on three (cases 1,4,5), four (case 6), five (case 3), and seven occasions (cases 7,8). Except for infants 7 and 8 corneal diameters did not alter between the first and most recent readings. Infants 7 and 8 were twins born at 25 weeks gestation. Both were extremely ill and developed grade 3-plus acute ROP. One month before term the corneal measurements were $9.0 \mathrm{~mm}$ in each eye of both infants. At term these were $9.5 \mathrm{~mm}$ in all four eyes, at 3 months corrected age $9.5 \mathrm{~mm}$ in each eye of one infant and $10.0 \mathrm{~mm}$ in the twin. By one year the diameters in infant 7 were, right $10.0 \mathrm{~mm}$ and left $10.0 \mathrm{~mm}$, and for the twin (case 8) $10.5 \mathrm{~mm}$ in the right eye and $11.0 \mathrm{~mm}$ in the left.

In two infants (cases 4 and 7) microcornea was bilateral, while in the other six it was unilateral. Microcornea involved the eye more severely affected by cicatricial ROP in five, while in the remaining infant there was no significant difference in the retinal appearance of the two eyes.

\section{Discussion}

The eight infants presented herein all had microcornea in association with cicatricial ROP. In six the condition was unilateral and in two bilateral. In two infants corneal diameters were not measured until $3^{1 / 2}$ years of age, by which time the ROP process had reached a stable cicatricial stage. For the remaining six infants, however, measurements began from 39.0 to 48.0 weeks postmenstrual age, at a time when ROP was either still in the acute phase or just entering the cicatricial phase. For the six infants with adequate data across both acute and cicatricial phases (cases $1,3,4,6,7,8$ ) no reduction of corneal diameter was detected after the first reading, and in these infants microcornea is likely to be due to a failure of growth and not to secondary globe shrinkage. In five of the six unilateral cases the smaller cornea was in the eye containing the more advanced cicatricial ROP, though in one infant (case 8), while there was no significant difference in ROP between the two eyes, yet a minor degree of microcornea $(0.5 \mathrm{~mm})$ of one eye was present.

Accurate assessment of corneal diameter in infancy is difficult. Our readings are not suitable for the study of corneal growth, but they do indicate a trend and can be used to detect interocular differences. At birth (full term) the horizontal corneal diameter (HCD) is $10.0 \mathrm{~mm}$, reaching adult values some time in the first year. ${ }^{111}$ The normal adult 'white to white' HCD is 11.64 (SD 0.49) $\mathrm{mm}$. ${ }^{12}$

Terry, ${ }^{2}$ Cohen et al. ${ }^{5}$ and King, ${ }^{3}$ in the early literature on ROP, noted microphthalmos as a feature of severe cicatricial retrolental fibroplasia. King implied that the retrolental membrane inhibited ocular growth, while Owens discussing that paper stated: 'in none of the eyes in which retrolental fibroplasia developed was the cornea smaller before the onset of the disease in the retina' ${ }^{3}$ No corneal measurements were contained in these articles, though the authors' observations that the cornea is normal initially and fails to grow is also our impression and confirmed by cases 7 and 8 . We do not consider a retrolental membrane to be the sole cause of delayed ocular growth, as in only four eyes of three of our infants did a membrane develop. Furthermore in our infants ocular growth was abnormal before this late stage. In all probability this is not specific to ROP but a consequence of severe ocular disease, particularly if involving the anterior section of the eye, during this period of ocular growth. We conclude therefore that growth may be adversely affected during severe acute stages of ROP and is not necessarily a sign of advanced cicatricial disease. We also found, with the exception of case 8 , where the acute ROP and cicatricial ROP were symmetrical, the 
microcornea present in the eye with the more advanced disease. Machemer ${ }^{13}$ has recently discussed retinal tissue contraction in advanced ROP, and it would not be surprising for late shrinkage of the globe to occur sometimes, though this was not a feature seen in our study.

Since ocular ultrasound was not possible in this study, it is not known whether microcornea is associated with microphthalmos in our patients. Microphthalmos in ROP has been confirmed by A scan ultrasound, ${ }^{67}$ but axial length does not necessarily correlate with the degree of myopia. ${ }^{14}$ Hittner et al. ${ }^{1}$ failed to correlate myopia with increased corneal curvature, though all their patients had received surgical treatment which itself could have adversely affected ocular growth. In association with microcornea we found myopia in four eyes of three infants, no refractive error in two eyes of two infants, while in three infants a retrolental mass precluded retinoscopy. Anomalies of corneal curvature may be a factor for myopia in some cases of ROP.

Microcornea has been recognised as a feature of advanced ROP since the first descriptions of this condition, but the pattern of ROP has changed over the past 30 years, and we have shown this also occurs with mild cicatricial ROP, though the frequency of this association is unknown. Cases 1,6 , and 7 also illustrate that bilateral acute symmetrical ROP can lead to asymmetrical cicatricial ROP.

Microcornea/microphthalmos is a feature of many ocular malformations, some of which have important genetic implications. This preliminary study indicates that the presence of microcornea or microphthalmos does not eliminate ROP as a differential diagnosis in infants with this abnormality or leucocoria-all the more so since on occasion ROP can occur in full term infants not exposed to supplementary oxygen. ${ }^{15}$
We thank Mrs Jill Wood for typing the manuscript.

References

1 Hittner HM, Rhodes LM, McPherson AR. Anterior segment abnormalities in cicatricial retinopathy of prematurity. Ophthalmology (Rochester) 1979; 86: 803-16.

2 Terry TL. Ocular maldevelopment in extremely premature infants. JAMA 1945; 128: 582-5.

3 King MJ. Retrolental fibroplasia. Arch Ophthalmol 1950; 43: 694-709.

4 Reese AB, Stepanik J. Cicatricial stage of retrolental fibroplasia. Am J Ophthalmol 1954; 38: 308-16.

5 Cohen J, Alfano JE, Boshes LD, Palmgreen C. Clinical evaluation of school age children with retrolental fibroplasia. Am J Ophthalmol 1964; 157: 40-57.

6 Gitter KA, Meyer D, White RH, Ortolan G, Sarin LK. Ultrasonic aid in evaluation of leukocoria. Am J Ophthalmol 1968; 65: 190-5.

7 Steindler P. Sulla importanza delle techniche ultrasoniche nella diagnosi de fibroplasia retrolenticolare. Arch Rass Ital Ottalmol 1973; 3: 50-4.

8 Committee for the Classification of Retinopathy of Prematurity. An International Classification of retinopathy of prematurity. $B r$ J Ophthalmol 1984; 68: 690-7.

9 Reese AB, King MJ, Owens WC. A classification of retrolental fibroplasia. Am J Ophthalmol 1953; 36: 1333-7.

10 Weale RA. A biography of the eye: development, growth, age. London: Lewis, 1982.

11 Scammon RE, Armstrong EL. On the growth of the human eyeball and optic nerve. J Comp Neurol 1925; 38: 165219.

12 Martin DK, Holden BAA. New method of measuring the diameter of the in vivo human cornea. Am J Optom Physiol Opt 1982; 59: 436-41.

13 Machemer R. Description and pathogenesis of the late stages of retinopathy of prematurity. Ophthalmology (Rochester) 1985; 92: 1000-4.

14 Tasman W. Late complications of retrolental fibroplasia. Ophthalmology (Rochester) 1979; 86: 1724-40.

15 Schulman J, Jampol LM, Schwartz H. Peripheral proliferative retinopathy without oxygen in a full-term infant. $A m J$ Ophthalmol 1980; 90: 509-14.

Accepted for publication 28 May 1986. 